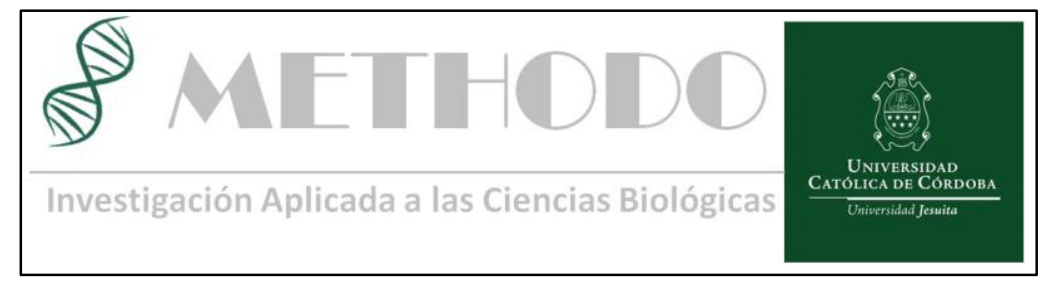

CASO CLINICO Methodo 2018;3(2):45-47

DOI: 10.22529/me.2018.3(2)07

Recibido 27 Ago. 2017 | Aceptado 26 Mar 2018 | Publicado 30 Jun 2018

Reporte breve

\title{
Enfermedad sistémica relacionada con IgG4 en un paciente asintomático.
}

\section{Systemic IgG4-related disease in an asymptomatic patient.}

\author{
Gallmann $\mathrm{AL}^{1}$, Arce $\mathrm{MG}^{1}$,Camporro $\mathrm{FA}^{1}$
}

\section{Introducción:}

La enfermedad relacionada con IgG4 (ER-IgG4) es una enfermedad rara, sistémica, fibroinflamatoria con hallazgos histopatológicos característicos en los órganos afectados. ${ }^{1}$

\section{Caso clínico:}

Paciente masculino, asintomático, de 39 años, con antecedentes de hipotiroidismo, consulta para un control de salud. Las pruebas de laboratorio mostraron anemia con una hemoglobina de $11,7 \mathrm{~g} / \mathrm{dl}$ y Cr de $2,8 \mathrm{mg} / \mathrm{dl}$. La orina de $24 \mathrm{hs} \mathrm{mostró}$ proteinuria de $3000 \mathrm{mg}$. Una tomografía computada mostró la presencia de un riñón derecho aumentado de tamaño y una imagen nodular de $2,6 \mathrm{~cm} \times 1,8 \mathrm{~cm}$ con bordes irregulares comprimiendo el uréter proximal. Se colocó un pig tail y se obtuvo una biopsia a través de una laparotomía exploratoria. La histología fue compatible con fibrosis retroperitoneal con un gran infiltrado inflamatorio linfoplasmocitario. La fosfatasa alcalina y la ganaglutanil transpeptidasa aumentaron

gradualmente hasta valores de 1328U/I y 345U/I respectivamente. $\mathrm{El}$

proteinograma mostró gammaglobulinas aumentadas en $1,46 \mathrm{mg} / \mathrm{dl}$, con $\mathrm{IgG}$ total de $1715 \mathrm{mg} / \mathrm{dl}$; En el dosaje de subclases de la IgG4 estaba dentro de límites normales. Se realizó una biopsia hepática que también demostró infiltrado linfoplasmocitario. Ante la sospecha de enfermedad por IgG4, se solicitó inmunohistoquímica en ambas biopsias, que fueron positivas para IgG4(Figura)1. El paciente fue tratado con dosis decrecientes de meprednisona. Tres meses después, todos los parámetros del laboratorio estaban dentro de los límites normales.

Los hallazgos del sedimento urinario en nuestro paciente fueron sugestivos de nefritis túbulo intersticial, que se produce en el $30 \%$ de los pacientes con ER-IgG4. ${ }^{4}$

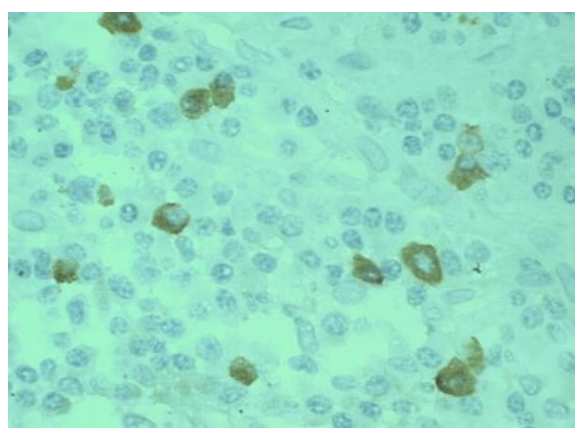

Figura 1. Las técnicas de inmunohistoquímica demuestran Ac. monoclonal para IgG positivos en los plasmocitos de la lesión y Ac. monoclonal para IgG4 positivo.

\section{Conclusión:}

Aunque la presentación inicial de la ER-IgG4 puede ser no específica o más bien sugerir otras enfermedades más comunes, no encontramos ningún caso en la literatura de ER-IgG4 diagnosticada en pacientes asintomáticos. Los sitios más frecuentemente afectados son las glándulas pancreáticas, salivales y ganglios linfáticos. La afectación renal, aórtica, retroperitoneal y pulmonar se describe con frecuencia ${ }^{2}$ a nivel hepático, los pacientes pueden presentar pseudotumor inflamatorio, colangitis esclerosante, hepatitis autoinmune o, como en 
nuestro caso, un infiltrado linfoplasmocitario sutil de IgG4 solo demostrado por la biopsia hepática. ${ }^{3}$ Los hallazgos del sedimento urinario en nuestro paciente fueron sugestivos de nefritis tubulointersticial, que se produce en el $30 \%$ de los pacientes con ER-IgG4. ${ }^{4}$

El diagnóstico tiene tres pilares: radiológico (masas en uno o más órganos), serológico (IgG4 con valores superiores o iguales a $135 \mathrm{mg} / \mathrm{Dl}$ ) e histológico (fibrosis, infiltrado linfoplasmocitario o más de 10 células plasmáticas IgG4 (+) por campo, con una relación IgG4/IgG total superior al $40 \%)^{5}$

En nuestro caso, el criterio serológico no se cumplió, sin embargo, este es el menos sensible, ya que hasta el $10-30 \%$ de los pacientes con ERIgG4 pueden presentar esta inmunoglobulina dentro rango normal. ${ }^{6}$

\section{Introduction:}

IgG4 related disease (ER-IgG4) is a rare, systemic, fibro-inflammatory disease with characteristic histopathological findings in ffected organs1.

\section{Clinical case:}

This is a 39-year-old asymptomatic male patient with a history of hypothyroidism who consults for his regular health checkup. The laboratory tests showed anemia with a hemoglobin of $11.7 \mathrm{~g} / \mathrm{dL}$ and creatinine of $2.8 \mathrm{mg} / \mathrm{dL}$. The 24 -hour urine showed proteinuria of $3000 \mathrm{mg}$. A computed tomography scan showed the presence of an enlarged right kidney and a nodular image of 2.6 $\mathrm{cm} \times 1.8 \mathrm{~cm}$ with irregular borders compressing the proximal ureter. A pig tail was placed and a biopsy sample was obtained through an exploratory laparotomy. The histology was compatible with retroperitoneal fibrosis with a large lymphoplasmacytic inflammatory infiltrate. The alkaline phosphatase and gammaglutamil transpepidase gradually increased reaching values of $1328 \mathrm{u} / \mathrm{i}$ and $345 \mathrm{u} / \mathrm{I}$ respectively. The proteinogram showed increased gamma globulins of $1.46 \mathrm{mg} / \mathrm{dl}$, with a total $\mathrm{IgG}$ of $1715 \mathrm{mg} / \mathrm{dL}$; IgG4 was within normal limits. A hepatic biopsy was performed which also demonstrated lymphoplasmacytic infiltrate. Upon suspicion of systemic IgG4 disease, an immunohistochemistry was requested in both biopsies samples which showed IgG4 positive immunoblotting (Figure). The patient was started with decreasing doses of meprednisone. Three months later, all the laboratory pramenters were within normal limits.

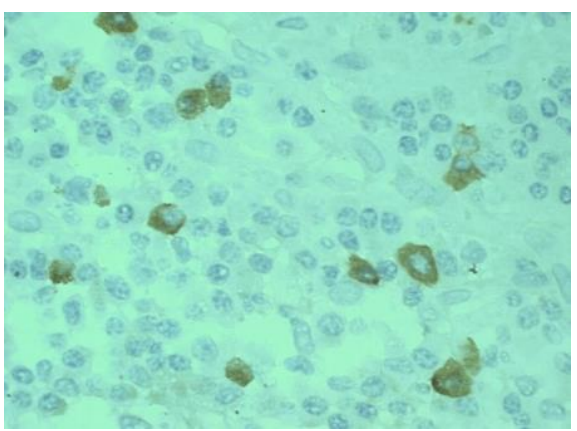

Figure 1. Les techniques immunohistochimiques démontrent Ac. anticorps monoclonal pour IgG positif dans les cellules plasmatiques de la lésion et Ac. monoclonal pour l'IgG4 positive

\section{Conclusion:}

Although the initial presentation of the ER-IgG4 may be non-specific o rather suggest other more common diseases, we have found no cases in the literature of ER-IgG4 diagnosed in asymptomatic patients. The most frequent affected sites are the pancreatic and salivary glands as well as lymph nodes. Renal, aortic, retroperitoneal and pulmonary involvement are frequently described. ${ }^{2}$ At the liver level, patients may present with inflammatory pseudotumors, sclerosing cholangitis, autoimmune hepatitis, or, as in our case, with a subtle lymphoplasmacytic IgG4 infiltrate only demonstrated by the liver biopsy ${ }^{3}$

The urinary sediment findings in our patient was suggestive of tubulointerstitial nephritis, which occurs in $30 \%$ of patients with ER-IgG4. ${ }^{4}$

The diagnosis of ER-IgG4 has three pillars: the radiological (masses in one or more organs), the serological (the elevation of IgG4 with values greater than or equal to $135 \mathrm{mg} / \mathrm{dL}$ ) and the histological (fibrosis, lymphoplasmacytic infiltrate or the presence of more than $10 \mathrm{IgG} 4(+)$ plasma cells per field, with a total $\mathrm{IgG} 4 / \mathrm{IgG}$ ratio greater than $40 \%)^{5}$

In our case, the serological criterion was not fulfilled in this case, however this is the least sensitive criterion, since up to $10-30 \%$ of the patients with ER-IgG4 may present with this immunoglobulin within normal range. ${ }^{6}$.

\section{Bibliografía:}

1- Stone, J. H. IgG4 related disease: nomenclature, clinical features, and treatment. Semin. Diagn. Pathol 2012; 29: 177-190.

2- Inoue D, Yoshida $\mathrm{K}$, Yoneda $\mathrm{N}$, Ozaki $\mathrm{K}$, Matsubara T, Nagai K, et al. IgG4- related disease: Dataset of 235 consecutive patients. Medicine (Baltimore) 2015; 94: e680 
3- Kamisawa T, Funata N, Hayashi Y, et al. A new clinicopathological entity of IgG4-related autoimmune disease. J Gastroenterol 2003; 38: 982-984.

4- Stone JH, Zen Y, Deshpande V. IgG4-related disease. N Engl J Med 2012; 366:539-551

5- Kazuichi O, Kazushige U, Masanori K, Hideaki M, Makoto T. Recent advances in the concept and diagnosis of autoimmune pancreatitis and IgG4related disease. J Gastroenterol 2011; 46: 277-288.

6- Carruthers MN, Khosroshahi A, Augustin T, et al. The diagnostic utility of serum IgG4 concentrations in IgG4-related disease. Ann Rheum Dis 2015; 74:14-18.

\section{Palabras claves:}

Enfermedad relacionada a IgG4. Fibrosis retroperitoneal

\section{Keywords:}

IgG4-related disease. Retroperitoneal fibrosis

${ }^{1}$ Servicio de Clínica médica, Clínica Universitaria Reina Fabiola.

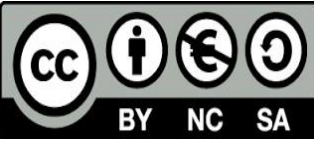

